\title{
Defining social change as social action: higher education's role in addressing social change
}

\author{
Mazia Yassim \\ University of Greenwich, UK
}

\begin{abstract}
Social issues that need addressing have never been in short supply and, despite regular calls for action, some of them recur with unfortunate regularity. Higher education institutions have a key role to play in addressing social change issues, through the education and empowerment of students. Based on critical discourse, this article puts forward the opinion that effective development of students as social change makers requires education and impact measurement.
\end{abstract}

\section{Context}

The world we currently live in has undergone changes for the better in very many ways, from social and economic to technical aspects. We cannot deny that we have made great strides in very many areas. However, there are some fundamental, seemingly recurrent issues which affect society in many parts of the world. Racism is one of them.

Racism is not a new phenomenon and goes back centuries. We have lost count of the number of campaigns to address racism and the number of world leaders who promised to address it. But how much has actually changed? Recent resurgence of the 'Black Lives Matter' movement as a result of George Floyd's death in the United States of America is an unfortunate and uncomfortable reminder to us all that this issue has not been effectively dealt with.

\section{The efforts of higher education institutions to raise awareness of social issues}

The global financial crisis of 2007/8 was a wake-up call for many educational institutions, especially for Business Schools, to reform educational approaches. Following critique of the focus of higher education institutions (HEls) on developing economic beings (Abbott, 2007), many HEls have taken measures to instil social consciousness as part of their graduate development (Iverson and James, 2010; Rountree and Koernig, 2015) and have introduced various initiatives. These include incorporating the 'Sustainability Development Goals' (SDGs) of the United Nations (UN), appointing sustainability champions, promoting an inclusive curriculum and signing up to the UN Principles for Responsible Management Education (PRME), aimed at transforming business and management education. Given all these initiatives, why do we still encounter evidence of racial insensitivity and abuse? For instance, businesses and brands are often foremost in their support for challenges to racism and for movements such as Black Lives Matter. On the other hand, they may contradict themselves, for example by producing blackface sweaters (Gucci) and exploiting movements such as Black Lives Matter for commercial gain (Pepsi's use of Kendall Jenner in an advert depicting a protest). These are some constant reminders to us in HEls that we need to do more and the recent resurgence of the Black Lives Matter movement should be prompting 
us to review what we do and to see what more we can do. HEls are doing well in raising awareness of social issues, but just being aware is not enough - it is now time to focus on action.

\section{Moving on from awareness to action}

Despite the various efforts by HEls to build social change agendas into their practices, there is almost no evidence of the effectiveness of these methods. Unfortunately, to date, objective measurement of the impact on our students of social change initiatives has been negligible and so there is no reliable means of knowing whether our graduates are socially active in their employment arena or in life in general. We also remain in the dark as to whether their increased social consciousness is influencing their lives - and, if so, how - and also, in particular, employment practices. So how may we ensure that we move from merely raising awareness to facilitating action? There are at least two ways by which we can do this - education and measurement.

An HEl wishing to be successful in embedding sound practice for educating students about social change must, with full senior management buy-in, establish it as an integral part of its culture. It must also ensure that social change is given the same curricular weight and profile by all disciplines. A framework that can help with this is the Cultural Competency for Social Justice (CCSJ) proposed by Goodman (2013). The author suggests that social justice should be part of the culture we develop in students and, in order to inspire a sense of social justice and cultural competence in our students, we need to facilitate their development through five stages:

1. Self-awareness - addresses, among other things, our own prejudices, biases and internalised notions of superiority or inferiority.

2. Understanding and valuing others - addresses aspects such as social identities and culture of others and the ability to value those who have different perspectives.

3. Knowledge and societal inequities - is about understanding the history, ideologies and various manifestations of inequalities.

4. Skills to interact effectively with a diversity of people in different contexts - is about the skills needed to deal with conflict arising from cultural differences, social identities and inequality.

5. Skills to foster equity and inclusion - is focused on developing the skills required to transform institutions and create social change.

Part of this education of students should also build their confidence in their own ability to create change. It is important that we do not allow our students to fall into the downward spiral of a feeling of individual helplessness 'What can one person do?' or 'I don't have the power to make any difference.' Research into the development of people from children to adults has shown that empathy, positive emotions and a growth mindset all have a positive impact on prosocial behaviour and social responsibility ( Oros and Fontana Nalesso, 2015; Hernández and Carranza Esteban, 2017). Every one of us, regardless of who we are and where we are on our career ladder, can influence society positively. It is important that our students graduate with not just the confidence to exercise their discipline or employmentspecific skills and knowledge, but also with full competence and confidence to be able to create and deliver social change. 
Of course, to educate our students effectively about social change and to develop this social justice cultural competence, we need to ensure that all our academics receive the relevant training and support to embed into the curriculum the means of generating such competence and to convert it into suitable content.

Measurement of social change initiatives is essential if we are do more than merely demonstrate evidence of impact: to understand how and where we can improve. According to Ratliff (2019) the measurement starts from embedding social change cultural competences into learning outcomes across a programme of study. This ensures that, at a programme level in every discipline, emphasis is given to developing student skills to create social change. As well as programme-level measurements, institutional and sector-wide measurements are also key to driving this change. In the higher education (HE) sector and in a given market, measurement of the standing and reputation of HEls needs to take into account the level of social change measures that are implemented effectively. Tracking of alumni progress and career profiles should include consideration of their social change engagements. National surveys - such as Destination of Leavers from Higher Education (DLHE), National Student Survey (NSS) and Postgraduate Taught Experience Survey (PTES) - must include social change components so that social change education forms part of the focus of all HEls.

\section{Conclusion}

HE has a duty to consider social change as a necessary part of student development (Simpson, 2014). In order to ensure that social justice and support for related movements such as Black Lives Matter do not remain a futile concept, there must be a focus on education and measurement. Students need to understand how to define social issues - in terms of specific change action within any given discipline or sector - and have the skills and confidence to be able to create and deliver these change actions. Measurements at programme, institutional and even national levels are key to ensuring that social change remains at the forefront of the HE sector's practices.

\section{Reference list}

Abbott, A. (2007) 'Education for humanity: A challenge within globalisation.' The International Journal of the Humanities, 5, 223-227.

Goodman, D.J. (2013) 'Cultural Competency for Social Justice,' The CSJC Blog. Available at: https://acpacsje.wordpress.com/2013/02/05/cultural-competency-for-social-justice-bydiane-j-goodman-ed-d/ (Accessed: $1^{\text {st }}$ August 2020).

Hernández, R.M. and Carranza Esteban, R.F. (2017) 'Happiness, optimism and selfrealization in students from a higher education program for adults.' [Felicidad, optimismo y autorrealización en estudiantes de un programa de educación superior para adultos.] Interdisciplinaria, 34, 307-325.

Iverson, S.V. and James, J.H. (2010) 'Becoming "effective" citizens? Change-oriented service in a teacher education program.' Innovation in Higher Education, 35, 19-35. 
Oros, L.B. and Fontana Nalesso, A.C. (2015) 'Socially skilful children: How much influence do positive emotions and empathy have?' [Niños socialmente hábiles: ¿Cuánto influyen la empatía y las emociones positivas?] Interdisciplinaria, 32,109-125.

Ratliff, D. (2019) 'Educating for justice: Curricular social justice education at institutions of Higher Education,' Jesuit Higher Education: A Journal, 8, 37-48.

Rountree, M.M. and Koernig, S.K. (2015) 'Values-based education for sustainability marketers: Two approaches for enhancing student social consciousness,' Journal of Marketing Education, 37, 5-24.

Simpson, J.S. (2014) Longing for Justice: Higher Education and Democracy's Agenda, Toronto: University of Toronto Press. ISBN: 978-0-8020-9670-8 